\title{
Die Papierverarbeitung.
}

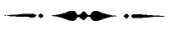

II.

Die Buntpapier-, Tapeten-, Briefumschlag-, Düten- oder Papiersack-, Papierwäsche- und photographische Papier-Fabrikation.

\author{
Praktisches Handbuch
}

für Techniker, Buntpapier-, Tapeten- und Dütenfabrikanten, Direktoren.

Mit 278 Illustrationen.

Vun

\section{Max Schubert}

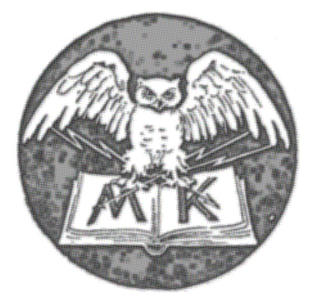

BERLIN W.

Verlag von M. KRAYN.

1)(1)1. 
$\overline{\text { Druck ron Pass \& Garleb, Berlin W. 35. }}$ 